\author{
Robert Babuka, \\ Ing. MBA, Mendel University in Brno, Czech Republic \\ Andrea Sujova, \\ Ph.D., Associate Professor, Mendel University in Brno, Czech Republic \\ Vaclav Kupcak, \\ Ph.D., Associate Professor, Mendel University in Brno, Czech Republic
}

\title{
SCENARIO MANAGEMENT OF CASCADE WOOD USE: COMPARISON OF SOCIAL AND ECONOMIC INDICATORS
}

\begin{abstract}
The innovation of wood-processing technology significantly improves the material conversion of wood into primary processing products. However, the total value of the processed wood in the outputs of the primary processing depends on both the total volume and the wood flow structure in the cascade of manufacturing. The paper is focused on modelling and comparison of different scenarios by identifying the current flow of timber and links in the cascade of processing in the Czech Republic to the development of selected social and economic indicators. In the analysis, three different scenarios were used. The first scenario took into account only the potential for export absorption to current processing capacities. The second scenario was based on the first, adding parameters for the increase of technological efficiency, and the third scenario beyond the first took account of the capacity increase by investing in the sawn wood and pulp production segment. The results showed that to achieve a balanced value creation and societal effects in the form of high or qualified employment and maximize contributions to the social system, it is necessary to create conditions for the allocation of timber for export. At the same time, it is necessary to optimize the structure of production so that the flow has been as large as possible in the cascade and at the same time it has been able to absorb the impacts from the temporary or changing conditions of the available raw wood volume and structure. Appropriate option, therefore, appears to be a compromise between scenarios number 2 and 3. Thus, to strengthen the (technologically or logistically) stability of the existing capacities and to supplement them with the appropriate structure of several new investments in the production of timber and wood-based panels' production.
\end{abstract}

Keywords: wood flow, value from wood, revenues, added value, employment.

Introduction. After 1989, the system of economic governance in the Czech Republic changed and politically supported the direction of the open economy and business support, including the support of foreign investment inflow, which helped accelerate the development of domestic processing and replaced some outdated processing capacities. This process was completed in 2004 when the last major foreign investment was made in wood processing. During this period the volume of domestic wood processing has gradually increased. However, since 2004, the export of raw wood has begun to increase and today accounts for a quarter of the total volume of timber delivered for processing capacities from local sources (Green Report).

Finding a solution to the development of domestic wood processing and thus reducing the rate of export of raw wood is not only a matter of increasing capacity but, in particular, optimizing the structure of the processing, taking into account the current possibilities and the state of processing so as to support social and economic development at the same time.

In the solution, on one hand, the limitations in wood sources are seen. On the other hand, the material balance of resources and their consumption is the problem of ordering capacities and seeking optimal adjustment towards some key performance characteristics such as total production volume, maximum wood input and processing cascade producing as much raw material as possible for subsequent processing with additional value added. In essence, this is an optimization task with maximizing value and

Cite as: Babuka, R., Sujova, A., \& Kupcak, V. (2018). Scenario Management of Cascade Wood Use: Comparison of Social and Economic Indicators. Marketing and Management of Innovations, 4, 73-85. http://doi.org/10.21272/mmi.2018.4-07 
volume. Social and economic efficiency can be expressed by the share of the total value produced and the volume of input material (raw wood). The value is composed of both the total output volume and the output structure in particular. Countries producing predominantly lumber will not have as much added value as a country that produces pulp from the same volume of material.

This study allows modelling the scenario of cascade wood use with the most positive social and economic impacts. It is based on own findings on the structure of primary processing, material consumption and wood flow in the processing cascade. Proposed models or scenarios of changes in the processing structure allow to identify the development of selected indicators over the current processing base, which was used in detail at the level of economic data to generate actual performance characteristics, such as the number of employees per $1 \mathrm{~m}^{3}$ of input timber, the accounting value added per $1 \mathrm{~m}^{3}$ of input wood, which characterizes the socio-economic potential of the individual primary processing industries.

Literature review. The limitations of wood sources in domestic wood processing are described in the Material Flow Analysis (MFA) by authors at the regional level in the studies of Binder et al., 2004 and Mantau, 2015, at national levels by Hekkert et al. (2000) for the Netherlands, Hashimoto and Moriguchi (2004) for Japan, Piskur and Krajnc (2007) for Slovenia, Knaggs and O'Driscoll (2008) for Ireland, Cheng et al. (2010) for China, METLA (2011) for Finland, Weimar (2009) for Germany and also on the European Union as a whole (Mantau, 2012). The approach to the wood flow and its interpretation contains several options for a balanced approach, which is best captured in the work of Mantau (2015), who concluded this from the available information about wood sources and the volume of its utilization or consumption. It is possible to identify the strengths and weaknesses of processing and provide optimizations so that the wood flow will bring the greatest potential. The cascading principle, by presenting the utilization of wood resources in the German region, was used in the work of Taskhiri et al. (2016), which focused on the logistics networks for wood flow. The design of a quantitative wood flow chart in Japan was constructed by Kobayashi et al. (2017) in an aim to find possibilities for wood self-sufficiency. The method of Latta et al. (2013) contains the models thus far implemented and their mutual relation to express the balance between the wood sources and their utilization. It is a very complex approach. However, this approach is limited to the global level of wood sources and consumption, and can only be used for the national level. In the Czech Republic, several authors have dealt with wood sources and their determination, such as Kupčák and Pek (2015), who in their work focused on the wood source balance and points to their minimal level of use, based on the available official data sources (data from the Ministry of Agriculture and the Ministry of Industry).

The economic and social impacts of wood flow scenarios have been solved in several studies. Lenglet (2016) applied a similar approach to work of Mantau (2015) for material flow, in the context of the climate change policy and energy transformation for the use of wood for energy purposes and described the wood flow in France. The potential consequences of various scenarios of raw wood exports reduction policies were evaluated, namely subsidies to consumption or transformation and taxation of exports, on both economic outcomes for the different actors and material flows. Martire (2015) in his study conducted in the French region developed a holistic assessment method to support the forest-based sector. His presented method is suitable to deal with a competitive use of biomass, allowing the estimation of its positive impacts and the potential trade-offs for the existing business. The work was focused on primary processing of wood, and was calculated impacts of bioenergy developments in terms of costs for the concurrent industries using pulpwood, and employment and avoided GHG emissions at the regional level. Jasinevicius et al. (2017) in the study examined the impacts of increased wood utilisation in Lithuania on employment and the economic performance of the sector and they found out that opportunities for employment and the economic performance of the forest-based sector improved in all scenarios due to increased wood utilisation. 
Input data and methodology. The work contains available data provided by the Czech Statistical Office $(C S O, 2016)$ on the supply of timber to the domestic market and foreign trade in raw timber. On the basis of these input data, it was possible to make own calculations on available wood for industrial processing and to add them to the amount of wood that does not affect the statistics of timber deliveries on the domestic market. In particular, the calculated wood volume from forest owners not included in the official statistical survey (with a forest area of fewer than 200 hectares). The timber input volume thus obtained in domestic processing determines a deficit or surplus of raw material in the applied scenario.

The most important data source for our work, however, is the company's financial reporting data published within the collection of documents available at Business Registers (BRs). Where data were not available, on some companies were conducted surveys directly with representatives of companies with supplementary confirmation using publicly available data and, in some cases, personal meetings.

As a result, the analysis of consumption in domestic processing was based on an analysis of individual companies' sales and verified material utilization in each type of processing. Individual companies by primary processing segments have been questioned about the volume of their timber production and input and on this basis, the need for wood to be processed has been retrofitted. This allowed the application of scenarios to increase the volume of processing or to change the structure of the processing, taking into account the availability of the raw material or the estimated efficiency gain potential, to improve the yield of input raw material.

The study includes the capacity of firms representing $66 \%$ of processed wood in the Czech Republic. This volume of wood is divided into processing by primary processing sectors: coniferous lumber $37 \%$, deciduous timber $12 \%$, impregnation $80 \%$, veneers $100 \%$, coniferous plywood $100 \%$, hardwood plywood $100 \%$, OSB $100 \%$, DTD $100 \%$, MDF $100 \%$, pulp $100 \%$.

Above this set of companies, average values of the monitored indicators were created for each of the primary processing sectors as show tables 1-3. For veneers, coniferous plywood, OSB and chipboard, there are indicators of the only representatives on the Czech market. Company data is from 2014 to 2016.

Table 1 - Forest based industry Branch indicators for primary segments (part 1)

\begin{tabular}{|c|c|c|c|c|c|c|c|}
\hline Segment & 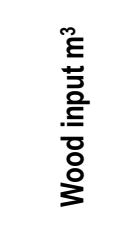 & 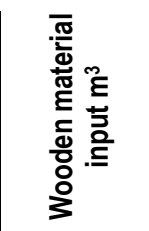 & 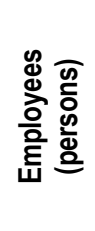 & 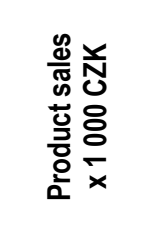 & 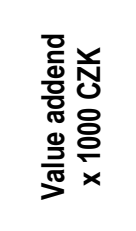 & 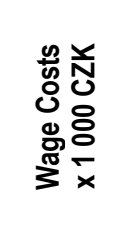 & 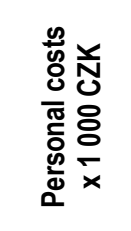 \\
\hline Softwood lumber & $2,938,850$ & $3,033,478$ & 1,113 & $10,990,270$ & $2,003,594$ & 381,405 & 531,868 \\
\hline Hardwood lumber & 60,694 & 60,693 & 205 & 214,507 & 45,628 & 35,236 & 47,892 \\
\hline Impregnation & 32,000 & 32,000 & 80 & 195,155 & 52,896 & 20,602 & 28,158 \\
\hline Veneers & 98,000 & 98,000 & 595 & 872,063 & 494,042 & 198,507 & 266,207 \\
\hline Softwood plywood & 64,000 & 64,000 & 120 & 311,000 & 96,000 & 27,599 & 40,618 \\
\hline Hardwood plywood & 48,000 & 48,000 & 228 & 316,890 & 118,699 & 52,438 & 77,174 \\
\hline$O S B$ & 960,000 & 960,000 & 75 & $3,402,583$ & 530,853 & 27,193 & 36,822 \\
\hline$P B$ & 570,000 & $1,530,000$ & 374 & $6,354,151$ & 883,947 & 144,438 & 194,445 \\
\hline$M D F^{*}$ & 250,000 & 500,000 & 569 & $2,021,379$ & 361,542 & 169,313 & 228,941 \\
\hline Pulp & $3,340,000$ & $4,590,000$ & 946 & $14,400,717$ & $3,324,430$ & 485,474 & 676,619 \\
\hline Total & $8,361,544$ & $10,916,171$ & 4,305 & $39,078,715$ & $7,911,631$ & $1,542,205$ & $2,128,744$ \\
\hline
\end{tabular}

Sources: CSO, BRs of companies of own database 
R. Babuka, A. Sujova, V. Kupcak. Scenario Management of Cascade Wood Use: Comparison of Social and Economic Indicators

Table 2 - Forest-based industry Branch indicators for primary segments (part 2)

\begin{tabular}{|c|c|c|c|c|c|c|c|c|}
\hline Segment & 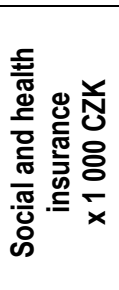 & 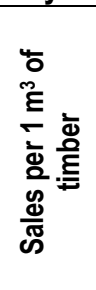 & 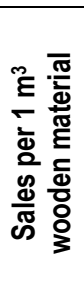 & 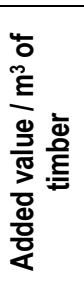 & 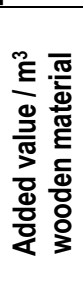 & 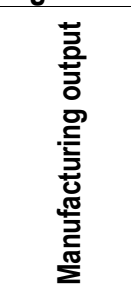 & 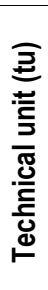 & 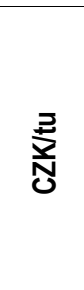 \\
\hline Softwood lumber & 150,463 & 3,740 & 3,623 & 682 & 660 & $1,726,892$ & $\mathrm{~m}^{3}$ & 6,364 \\
\hline Hardwood lumber & 11,557 & 3,534 & 3,534 & 752 & 752 & 33,059 & $\mathrm{~m}^{3}$ & 6,489 \\
\hline Impregnation & 7,556 & 6,099 & 6,099 & 1,653 & 1,653 & 32,000 & $\mathrm{~m}^{3}$ & 6,099 \\
\hline Veneers & 65,262 & 8,899 & 8,899 & 5,041 & 5,041 & 48,620 & $m^{3}$ & 17,936 \\
\hline Softwood plywood & 13,019 & 4,859 & 4,859 & 1,500 & 1,500 & 35,000 & $\mathrm{~m}^{3}$ & 8,886 \\
\hline Hardwood plywood & 24,736 & 6,602 & 6,602 & 2,473 & 2,473 & 19,500 & $m^{3}$ & 16,251 \\
\hline$O S B$ & 9,629 & 3,544 & 3,544 & 553 & 553 & 595,000 & $m^{3}$ & 5,719 \\
\hline$P B$ & 50,007 & 11,148 & 4,153 & 1,551 & 578 & 920,000 & $\mathrm{~m}^{3}$ & 6,907 \\
\hline$M D F^{*}$ & 59,628 & 8,086 & 4,043 & 1,446 & 723 & 270,000 & $\mathrm{~m}^{3}$ & 7,487 \\
\hline Pulp & 191,145 & 4,312 & 3,137 & 995 & 724 & 930,000 & $t$ & 15,485 \\
\hline Total & 583,002 & 4,674 & 3,580 & 946 & 725 & $4,610,071$ & & 8,477 \\
\hline
\end{tabular}

Sources: own calculations based on BRs of companies of own database

Table 3 - Forest-based industry Branch indicators for primary segments (part 3)

\begin{tabular}{|c|c|c|c|c|c|c|}
\hline Segment & 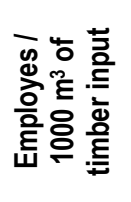 & 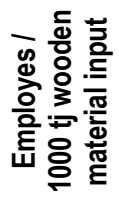 &  & 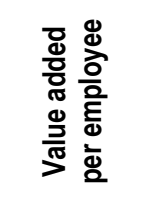 &  & 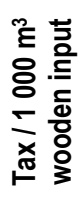 \\
\hline Softwood lumber & 0.38 & 0.37 & 50 & $1,800,174$ & 186,441 & 61 \\
\hline Hardwood lumber & 3.38 & 3.38 & 190 & 222,576 & $-2,739$ & -45 \\
\hline Impregnation & 2.50 & 2.50 & 236 & 661,200 & 3,081 & 96 \\
\hline Veneers & 6.07 & 6.07 & 666 & 830,323 & 34,428 & 351 \\
\hline Softwood plywood & 1.88 & 1.88 & 203 & 800,000 & 3,673 & 57 \\
\hline Hardwood plywood & 4.75 & 4.75 & 515 & 520,610 & 4,340 & 90 \\
\hline$O S B$ & 0.08 & 0.08 & 10 & $7,078,040$ & 133,606 & 139 \\
\hline$P B$ & 0.66 & 0.24 & 33 & $2,363,495$ & $-47,694$ & -31 \\
\hline$M D F^{*}$ & 2.28 & 1.14 & 119 & 635,399 & $-4,343$ & -9 \\
\hline Pulp & 0.28 & 0.21 & 42 & $3,514,197$ & 343,099 & 75 \\
\hline Total & 0.51 & 0.39 & 53 & $1,837,777$ & 653,892 & 60 \\
\hline
\end{tabular}

Notes to tables: MDF with parallel production PB and soft sawn wood and grey shadowed title represents coefficient used in the scenario modelling

Sources: own calculations based on BRs of companies of own database

Indicators for the production of deciduous plywood, OSB, pulp are consistent with the current state 
R. Babuka, A. Sujova, V. Kupcak. Scenario Management of Cascade Wood Use: Comparison of Social and Economic Indicators

and thus applicable to scenarios without reservation. Indicators for the timber production segment are based on the selection of companies that represent more powerful agents in their overall volume and position. This means that the coefficients generated per segment will show optimistic development towards the required concentration in the industry and performance improvement. This is also led by our own analysis of sawmill capacities, where can be seen the decline of micro and small firms and the improvement of productivity of existing micro, small and medium-sized companies due to support programs for regional companies. The application of the indicators for the sawmill industry must, therefore, be taken into account, subject to the set parameters. From the companies' data and created indicators, it was possible to use material breakdown conversion factors according to table 4 and to determine the basic model of primary wood processing for the total calculated capacity by table 5 .

Table 4 - Material utilization of raw wood for different manufacturing in the Czech Republic

\begin{tabular}{|l|l|l|l|}
\hline \multicolumn{1}{|c|}{ Indicator } & Volume & \multicolumn{1}{c|}{ Indicator } & Volume \\
\hline Softwood lumber & $1.72 \mathrm{~m}^{3}$ & Veneer & $2.04 \mathrm{~m}^{3}$ \\
\hline Hardwood lumber & $1.88 \mathrm{~m}^{3}$ & OSB & $1.61 \mathrm{~m}^{3}$ \\
\hline Impregnation & $1.07 \mathrm{~m}^{3}$ & MDF & $1.63 \mathrm{~m}^{3}$ \\
\hline Softwood plywood & $1.81 \mathrm{~m}^{3}$ & Pulp & $4.85 \mathrm{~m}^{3}$ \\
\hline Hardwood plywood & $2.43 \mathrm{~m}^{3}$ & Particleboard & $1.53 \mathrm{~m}^{3}$ \\
\hline
\end{tabular}

Sources: own calculations based on BRs of companies of own database

Table 5 - Basic structure for modelling scenarios

\begin{tabular}{|c|c|c|c|}
\hline $\begin{array}{l}\text { Timber Input / wooden } \\
\text { material input }\left(\mathrm{m}^{3}\right)\end{array}$ & $\begin{array}{l}\text { Manufacturing } \\
\text { seqments }\end{array}$ & \multicolumn{2}{|c|}{ Input material decomposition } \\
\hline 1 & 2 & 3 & 4 \\
\hline $7,948,276$ & \multirow{6}{*}{$\begin{array}{c}\text { Softwood sawmilling } \\
\text { (SSW) }\end{array}$} & lumber & $58.0 \%$ \\
\hline \multirow[t]{5}{*}{$7,948,276$} & & shrinking & $2 \%$ \\
\hline & & chips & $23 \%$ \\
\hline & & sawdust and shavings & $15 \%$ \\
\hline & & lost & $2 \%$ \\
\hline & & bark & $8 \%$ \\
\hline 511,321 & \multirow{6}{*}{$\begin{array}{c}\text { Hardwood sawmilling } \\
\text { (HSW) }\end{array}$} & lumber & $53 \%$ \\
\hline \multirow[t]{5}{*}{511,321} & & shrinking & $3 \%$ \\
\hline & & chips & $23 \%$ \\
\hline & & sawdust and shavings & $18 \%$ \\
\hline & & lost & $3 \%$ \\
\hline & & bark & $6 \%$ \\
\hline 32,258 & \multirow[t]{5}{*}{ Impregnation } & wood & $93 \%$ \\
\hline \multirow[t]{4}{*}{32,258} & & shrinking & $2 \%$ \\
\hline & & chips & $3 \%$ \\
\hline & & lost & $2 \%$ \\
\hline & & bark & $2 \%$ \\
\hline \multirow{6}{*}{$\begin{array}{l}63,636 \\
63,636 \\
\end{array}$} & \multirow{6}{*}{$\begin{array}{l}\text { Softwood plywood } \\
\text { (SPW) }\end{array}$} & veneer in panel & $55 \%$ \\
\hline & & shrinking & $8 \%$ \\
\hline & & side production & $9 \%$ \\
\hline & & chips & $20 \%$ \\
\hline & & $d u s t$ & $5 \%$ \\
\hline & & lost & $3 \%$ \\
\hline
\end{tabular}


R. Babuka, A. Sujova, V. Kupcak. Scenario Management of Cascade Wood Use: Comparison of Social and Economic Indicators

\begin{tabular}{|c|c|c|c|}
\hline 1 & 2 & 3 & 4 \\
\hline & & bark & $7 \%$ \\
\hline 53,659 & \multirow{7}{*}{$\begin{array}{c}\text { Hardwood plywood } \\
\text { (HPW) }\end{array}$} & veneer in panel & $41 \%$ \\
\hline \multirow[t]{6}{*}{53,659} & & shrinking & $6 \%$ \\
\hline & & side production & $4 \%$ \\
\hline & & chips & $38 \%$ \\
\hline & & dust & $7 \%$ \\
\hline & & lost & $4 \%$ \\
\hline & & bark & $7 \%$ \\
\hline 97,959 & \multirow[t]{7}{*}{$\operatorname{Veneer}(V)$} & veneer & $49 \%$ \\
\hline \multirow[t]{6}{*}{97,959} & & shrinking & $7 \%$ \\
\hline & & side production & $11 \%$ \\
\hline & & chips & $24 \%$ \\
\hline & & dust & $5 \%$ \\
\hline & & lost & $4 \%$ \\
\hline & & bark & $7 \%$ \\
\hline 959,677 & \multirow[t]{5}{*}{$O S B$} & wood & $62.00 \%$ \\
\hline \multirow[t]{4}{*}{959,677} & & shrinking and densification & $33.00 \%$ \\
\hline & & dust & $4.00 \%$ \\
\hline & & lost & $1.00 \%$ \\
\hline & & bark & $5 \%$ \\
\hline 59,180 & \multirow[t]{5}{*}{ MDF } & wood & $61.00 \%$ \\
\hline \multirow[t]{4}{*}{149,180} & & shrinking and densification & $37.00 \%$ \\
\hline & & dust & $1.00 \%$ \\
\hline & & lost & $1.00 \%$ \\
\hline & & bark & $7 \%$ \\
\hline $3,340,525$ & \multirow[t]{3}{*}{ Pulp (P) } & $\operatorname{wood}\left(\mathrm{m}^{3}\right)$ & 4.85 \\
\hline \multirow[t]{2}{*}{$4,590,525$} & & lost & $5 \%$ \\
\hline & & bark & $7 \%$ \\
\hline \multirow{5}{*}{$1,584,615$} & \multirow[t]{5}{*}{ Particleboard (PB) } & wood & $65.00 \%$ \\
\hline & & shrinking and densification & $33.70 \%$ \\
\hline & & dust & $1.00 \%$ \\
\hline & & lost & $0.30 \%$ \\
\hline & & bark & $7 \%$ \\
\hline
\end{tabular}

Sources: own calculations based on companies' data of own database

By identifying the current flow of timber and links in the cascade of processing, three different scenarios of cascades in wood use were modelled.

The first scenario took into account only the potential for export absorption to current processing capacities. The basic criterion for identifying the possible increase in wood processing from export was the calculation of the possibility to increase production by existing capacity. This significantly reduced the possibility of applying the entire volume of exports to the manufacturing process.

The second scenario was based on the first, adding parameters for the increase of technological efficiency. There were applied the technological efficiency for simplicity as a percentage increase in the raw material used for processing. This means that in the baseline scenario we used the efficiency factor of $58 \%$ in the lumber material balance and in this scenario, could increase it by $1 \%$. This has resulted in increased material efficiency for all primary processing segments. For a more detailed examination of the 
possibilities of technological change, concrete expressions can be applied according to reality. In order to model the evolution of changes in socio-economic indicators, this simplification has been used.

The third scenario beyond the first took account of the capacity increase by investing in the sawn wood and pulp production segment. This means that only the part of the volume that corresponds to the consumption of the existing capacities is removed from the export. This scenario corresponds to the most realistic possibilities of increasing both the capacity and the efficiency of the processing, and the option of adding the processing capacities to the already existing and analysed production capacity for lumber and pulp.

In all scenarios, the change against the basic model in selected indicators was evaluated, expressing the social dimension of the available business accounting data in the primary processing. In terms of socially oriented economic policy, it is important to achieve maximum employment and tax revenue in the growth of added value. That is why the following indicators for the evaluation were selected:

- number of employees;

- social and health insurance contributions;

- accounting value added;

- income tax.

The construction of the indicators is based on the real data of the companies converted into employees or $1 \mathrm{~m}^{3}$ of input raw materials. These economic performance coefficients are then used in the scenarios. The base model for scenarios, based on current company data, is, therefore, a benchmark for tracking change and determining the most appropriate variation with regard to the socio-economic bound of the primary woodworking industry.

Results and Discussion. The basic model "SO" of the woodworking cascade has at the input $13724007 \mathrm{~m}^{3}$ of wood and standard of indicators with the following values in table 6 .

Table 6 - Basic model - S0 scenario indicators

\begin{tabular}{|c|c|c|c|}
\hline $\begin{array}{c}\text { Number of } \\
\text { employees }\end{array}$ & $\begin{array}{c}\text { Social and health insurance } \\
\text { contributions }\end{array}$ & $\begin{array}{c}\text { Accounting Value } \\
\text { Added }\end{array}$ & Income Tax \\
\hline 7,360 & $875,430,323$ & $11,288,351,782$ & $937,465,113$ \\
\hline
\end{tabular}

Sources: own calculations

In conversion per employee and $1 \mathrm{~m}^{3}$ of timber input, indicators according to the scenario have the following values shown in table 7 .

Table 7 - Indicators in SO scenario in CZK

\begin{tabular}{|c|c|c|c|c|}
\hline Sales on $1 \mathrm{~m}^{3}$ & Sales per employee & Insurance $1 \mathrm{~m}^{3}$ & Added value $1 \mathrm{~m}^{3}$ & Tax on $1 \mathrm{~m}^{3}$ \\
\hline 4,166 & $7,769,220$ & 63.79 & 823 & 68.31 \\
\hline
\end{tabular}

Sources: own calculations

These results correspond to the observed primary production situation characterized by the volume of sales in relation to figure 1. Revenues are expressed as the sum of all outputs within the scenario recalculated by the determined average price based on the analysis of the accounting data and the verification of the representatives of the companies according to the primary processing segments. 


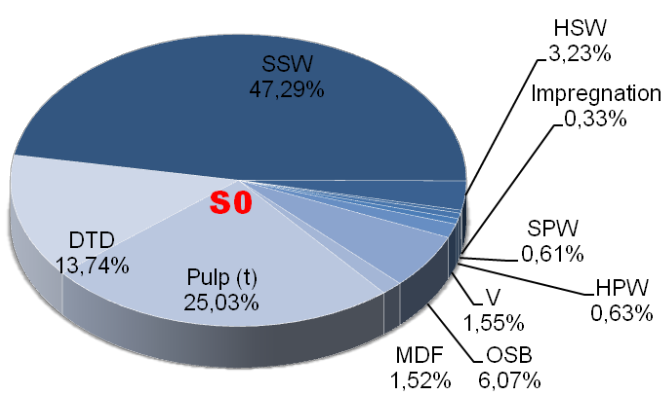

Figure 1 - Sales by basic model SO

Sources: own calculations

Scenario S1 with the maximum real wood absorption of timber exports reached a total volume of $17425184 \mathrm{~m}^{3}$ of raw timber at the input with the result of indicators according to table 8. In this scenario, a total of $78.6 \%$ of timber from the export volume of 4.1 million $\mathrm{m}^{3}$ was allocated.

Table 8 - Indicators in scenario S1 in CZK

\begin{tabular}{|c|c|c|c|}
\hline $\begin{array}{c}\text { Number of } \\
\text { employees }\end{array}$ & $\begin{array}{c}\text { Social and health insurance } \\
\text { contributions }\end{array}$ & Accounting Value Added & Income Tax \\
\hline 9,046 & $1,103,806,985$ & $14,139,015,125$ & $1,182,490,697$ \\
\hline
\end{tabular}

Sources: own calculations

The share of primary production capacities expressed in sales in this scenario changed according to figure 2 .

Sources: own calculations

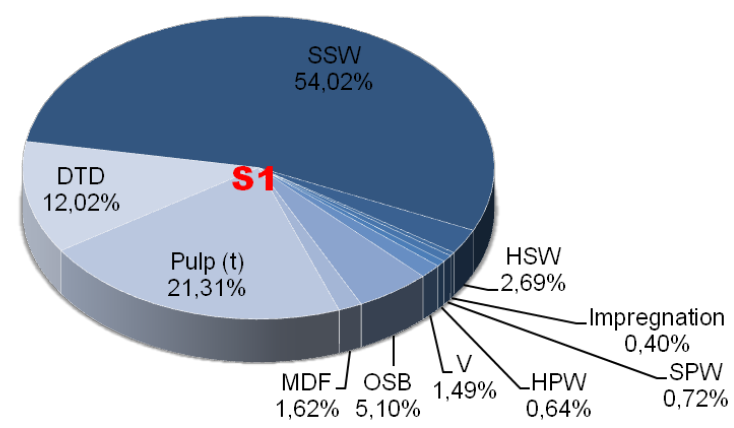

Figure 2 - Sales by scenario 1

In conversion per employee and $1 \mathrm{~m}^{3}$ of input, indicators according to scenario 1 have the following values shown in table 9 .

Table 9 - Ratio indicators in scenario 1

\begin{tabular}{|c|c|c|c|c|}
\hline Sales on $\mathbf{1} \mathbf{m}^{3}$ & $\begin{array}{c}\text { Sales per } \\
\text { employee }\end{array}$ & Insurance $1 \mathbf{~ m}^{3}$ & Added value $1 \mathbf{~ m}^{3}$ & Tax on $\mathbf{1} \mathbf{m}^{3}$ \\
\hline 4,107 & $7,911,409$ & 63.35 & 811 & 67.86 \\
\hline
\end{tabular}

Sources: own calculations 
R. Babuka, A. Sujova, V. Kupcak. Scenario Management of Cascade Wood Use: Comparison of Social and Economic Indicators

Scenario S2 of increased processing efficiency at an increase in a volume equivalent to scenario S1 has a total input of $17,225,169 \mathrm{~m}^{3}$ of wood, the difference being due to the higher material processing efficiency. In this scenario, the values of the indicators are given in Table 10.

Table 10 - Indicators in scenario S2 in CZK

\begin{tabular}{|c|c|c|c|}
\hline $\begin{array}{c}\text { Number of } \\
\text { employees }\end{array}$ & $\begin{array}{c}\text { Social and health insurance } \\
\text { contributions }\end{array}$ & $\begin{array}{c}\text { Accounting Value } \\
\text { Added }\end{array}$ & Income Tax \\
\hline 8,919 & $1,091,427,983$ & $13,996,719,485$ & $1,171,677,952$ \\
\hline
\end{tabular}

Sources: own calculations

In conversion per employee and $1 \mathrm{~m}^{3}$ of input, indicators according to the scenario have the following values shown in table 11.

Table 11 - Ratio indicators in scenario 2

\begin{tabular}{|c|c|c|c|c|}
\hline $\begin{array}{c}\text { Sales on } \\
\mathbf{1 ~ m}^{3}\end{array}$ & $\begin{array}{c}\text { Sales per } \\
\text { employee }\end{array}$ & $\begin{array}{c}\text { Insurance } \\
\mathbf{1 ~ m}^{3}\end{array}$ & $\begin{array}{c}\text { Added value } \\
\mathbf{1 ~ m}^{3}\end{array}$ & $\begin{array}{c}\text { Tax on } \\
\mathbf{1 ~ m}^{3}\end{array}$ \\
\hline 4,163 & $8,039,471$ & 63.36 & 813 & 68.02 \\
\hline
\end{tabular}

Sources: own calculations

The share of primary production capacities expressed in sales in this scenario changed according to figure 3 .

Sources: own calculations

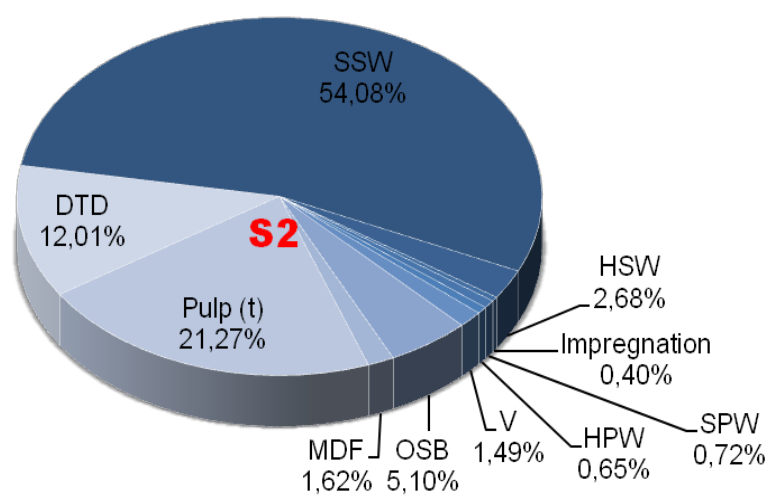

Figure 3 - Sales by scenario 2

The last S3 scenario, imitating the addition of two powerful existing capacities, has $15,155,557 \mathrm{~m}^{3}$ of raw timber at the input and takes from the exports 2.4 million $\mathrm{m}^{3}$ of timber (1.2 million saw logs and 1.2 million $\mathrm{m}^{3}$ of wood fibre) without taking into account the real availability of these assortments in an economically achievable reachable range. For this scenario, the results are in table 12.

Table 12 - Indicators in scenario S3 in CZK

\begin{tabular}{|c|c|c|c|}
\hline $\begin{array}{c}\text { Number of } \\
\text { employees }\end{array}$ & $\begin{array}{c}\text { Social and health insurance } \\
\text { contributions }\end{array}$ & $\begin{array}{c}\text { Accounting Value } \\
\text { Added }\end{array}$ & Income Tax \\
\hline 7,369 & $915,761,621$ & $12,561,758,624$ & $1,118,122,159$ \\
\hline
\end{tabular}

Sources: own calculations 
The share of primary production capacities expressed in sales in this scenario 3 changed according to figure 4 .

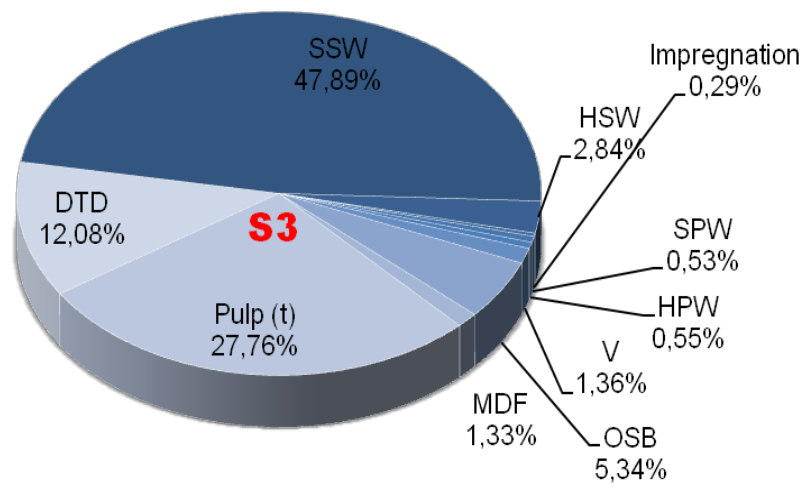

Figure 4 - Sales by scenario 2

\section{Sources: own calculations}

In conversion per employee and $1 \mathrm{~m}^{3}$ of timber input, indicators according to scenario 3 have the following values shown in table 13.

Table 13 - Ratio indicators in scenario 3

\begin{tabular}{|c|c|c|c|c|}
\hline $\begin{array}{c}\text { Sales on } \\
1 \mathrm{~m}^{3}\end{array}$ & $\begin{array}{c}\text { Sales per } \\
\text { employee }\end{array}$ & $\begin{array}{c}\text { Insurance } \\
1 \mathrm{~m}^{3}\end{array}$ & $\begin{array}{c}\text { Added value } \\
1 \mathrm{~m}^{3}\end{array}$ & $\begin{array}{c}\text { Tax on } \\
1 \mathrm{~m}^{3}\end{array}$ \\
\hline 4,288 & $8,818,129$ & 60.42 & 829 & 73.77 \\
\hline
\end{tabular}

Sources: own calculations

The results of the change of the indicators by individual scenarios can be seen in the graphical representation with an inserted table of values on figure 5, expressing the share of the monitored indicators.

The first scenario has a significant surplus of material in an existing processing cascade, creating the potential for growth of further processing by adding or changing the structure of the primary production. At the same time, this model maximizes employment but is not significant for value-added creation.

The second scenario increases the added value and increases the total number of employees against the current state. The third variant of the primary processing model was calculated by adding the lumber production capacity in the most modern functional variant in the Czech Republic with a volume of processing 1.2 million $\mathrm{m}^{3}$ of wood and the state-of-the-art production of pulp in the amount of 250 thousand tons (viscose fibre). This scenario had almost the same added value as the previous scenario but significantly lower the number of employees.

Conclusion. The aim of the study was not to find a concrete scenario which could be applied to the current situation in the primary processing of raw timber in connection with the high export of raw wood from the Czech Republic. It is necessary to take into account the more complex approach of policy assessment, policy mixes and sustainability transition as mentioned in Kivimaa et al. (2017).

In this study, the impacts of alternative domestic wood use scenarios for the Czech Republic economy were analysed, taking into account the socioeconomic performance of companies acting on the current structure of technology development. Future way of development of this study may follow conclusions from Humekoski et al. (2013) on the global view of structural changes and its operating environment inside 
the forestry industry. It is similar to Latta et al. (2013) with the need to define an equilibrium model.

In the baseline scenario, which served as a benchmark for benchmarking, the insufficient capacity of domestic processing is identified. From the data of individual companies, there is a great potential for increasing the processing capacity. This factor served to make the S1 scenario that was supposed to absorb the maximum raw timber from export. However, this scenario does not add additional value and brings only an increase in employment. By improving the efficiency of input processing (technologically) in the S2 scenario, better employment and revenue results will be achieved, but again a very small effect in added value. This results in a clear call for a change in the primary processing structure in the Czech Republic, where only the increase in capacity or technological improvement may not lead to an increase in added value. In the third S3 scenario, we have created a situation where we have added two economically most efficient capacities on the market.

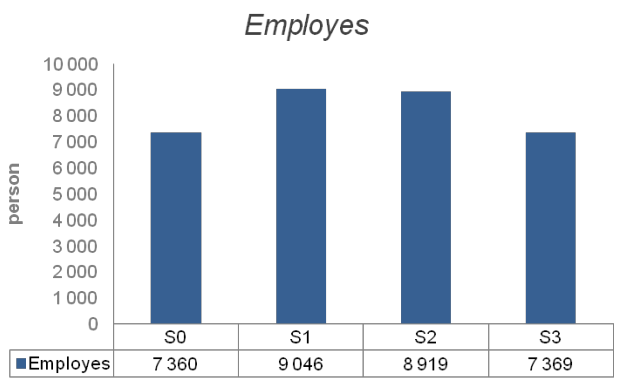

Income tax CZK/m3



Social security

$\mathrm{CZK} / \mathrm{m} 3$

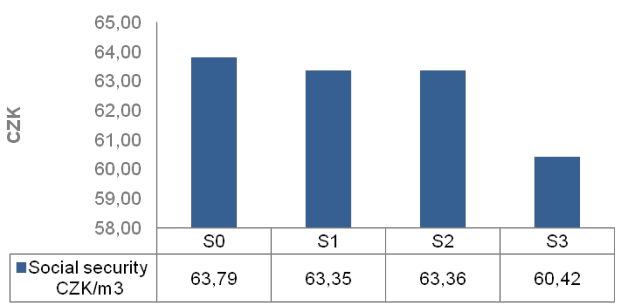

Sales $C Z K / m 3$

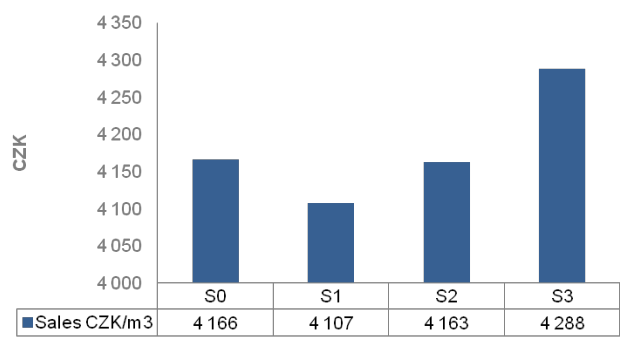

Sales per person

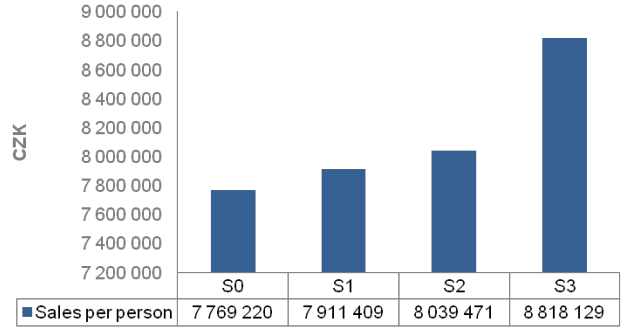

Added value CZK/m3

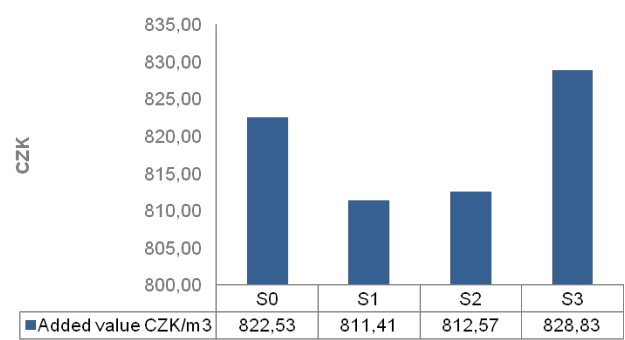

Figure 5 - Scenarios modelling results

Sources: own calculations

The result of this scenario confirms the need for a significant change in the structure of primary wood processing in the Czech Republic. However, the realization of such a development must respond to a 
more complex assessment of the changes in timber resources, and the testing of the timber flow in relation to the timber resources is a challenge that is needed to improve the quality of decision-making processes in other studies.

Funding: Authors are grateful for the support of the National Agency for Agricultural Research, Grant No. QK1820358.

\section{References}

Binder, C., Hofer, C., Wiek, A. \& Scholz, R. (2004). Transition towards improved regional wood flows by integrating material flux analysis and agent analysis: the case of appenzell ausserrhoden, Switzerland. Ecological Economics, 49(1), 1-17.

Czech Statistical Office CSO (2016). Forestry. Retrieved September 16, 2017 from https://www.czso.cz/csu/czso/lesnictvi-2016.

Hashimoto, S. \& Moriguchi, Y. (2004). Data book: Material and carbon flow of harvested wood in Japan. Center for global environmental research. Tech. rep., National Institute for Environmental Studies, Tsukuba.

Hekkert, M. P., Joosten, L. A. J. \& Worrell, E. (2000). Analysis of the paper and wood flow in the Netherlands. Resources, Conservation and Recycling, 30(1), 29-48.

Hurmekoski, E. \& Hetemäki, L. (2013). Studying the future of the forest sector: Review and implications for long-term outlook studies. Forest Policy and Economics, vol. 34, 17-29.

Cheng, S., Xu, Z., Su, Y. \& Zhen, L. (2010). Spatial and temporal flows of china's forest resources: development of a framework for evaluating resource efficiency. Ecological Economics, 69(7), 1405-1415.

Jasinevicius, G., Lindner, M., Verkerk, H. \& Aleinikovas, M. (2017). Assessing Impacts of Wood Utilisation Scenarios for a Lithuanian Bioeconomy: Impacts on Carbon in Forests and Harvested Wood Products and on the Socio-Economic Performance of the Forest-Based Sector. Forests 133(8), DOI: 10.3390/f8040133

Kivimaa, P., Kangas, H. L. \& Lazarevic, D. (2017). Client-Oriented Evaluation of "Creative Destruction" in Policy Mixes: Finnish Policies on Building Energy Efficiency. Transition, Energy Research \& Social Science, Policy mixes for energy transitions, 33 (2017), 115-27. DOI: 10.1016/j.erss.2017.09.002

Knaggs, G. \& O'Driscoll, E. (2008). Estimated woodflow for the republic of Ireland in 2007. Tech. rep., COFORD Processing/Products No 18.

Kobayashi, T., Sumitomo, Y. \& Nakada, T. (2017). Wood flow chart in Japan: Material and energy utilization. Journal of the Japan, Institute of Energy 96(7), 206-216. DOI: 10.3775/jie.96.206

Kupčák, V \& Pek, R. (2015). The level of the wood raw material base processing in the Czech Republic. Procedia Economics and Finance 34, 557-564. DOI: 10.1016/S2212-5671(15)01668-8

Latta G. J., Baker, R., Beach, S., Rose, A. \& McCarl, B. (2013). A multi-sector intertemporal optimization approach to assess the GHG implications of U.S. forest and agricultural biomass electricity expansion. Journal of Forest Economics 19(4), 361-383. DOI: 10.1016/j.jfe.2013.05.003

Lenglet, J. (2016). Material flow analysis of the forest-wood supply chain: A consequential approach for logs export policies in France. Retrieved March 5, 2017 from http://faere.fr/pub/Conf2016/Caurla_mfa-wood-sector_FAERE2016.pdf

Mantau, U. (2012). Wood flows in Europe (EU27). Tech. rep., Project report. Celle 2012.

Mantau, U. (2015). Wood flow analysis: Quantification of resource potentials, cascades and carbon effects. Biomass and Bioenergy, 2015:28-38. DOI: 10.1016/j.biombioe.2014.08.013

Martire, S. (2015). Wood flow modelling for a more sustainable regional forest-based sector. In: Proceedings of the Conference Towards a Sustainable Bioeconomy, Barcelona, Spain, pp. 326-334.

Metla, (2011). Wood flows in Finland 2010. Finnish statistical yearbook of forestry. Tech. rep., METLA.

Piskur, M. \& Krajnc, N. (2007). Roundwood flow analysis in Slovenia. Croatian Journal of Forest Engineering, 28(1), 39-46.

Taskhiri, M. S., Garbs, M. \& Geldermann, J. (2016). Sustainable logistics network for wood flow considering cascade utilization. Journal of Cleaner Production 110, 25-39. DOI: 10.1016/j.jclepro.2015.09.098

Weimar, H. (2009). Der holzfluss in der bundesrepublik Deutschland 2009. Tech. rep, Methode und Ergebnis der Modellierung des Stoffflusses von Holz. Johan Heinrich von Thunen - Institut fur Forst und Holzwirtschaft, Arbeitsbericht.

P. Бабука, МВА, Університет Менделя у Брно (Чехія);

A. Суджова, Ph.D., доцент, Університет Менделя у Брно (Чехія);

B. Купчак, Ph.D., доцент, Університет Менделя у Брно (Чехія).

Сценарний менеджмент каскадного використання лісових ресурсів: порівняння економічних та соціальних індикаторів

Інноваційні технології деревообробки підвищують якість та еффективність обробки деревини як первинного ресурсу. При цьому автори зазначають, що якість та вартість обробленої деревини на виході залежить від обсягу та структури потоку 
R. Babuka, A. Sujova, V. Kupcak. Scenario Management of Cascade Wood Use: Comparison of Social and Economic Indicators

деревини при каскадному типі виробництва. Метою даної статті $є$ моделювання та порівняння різних сценаріїв побудови потокового типу виробництва з використанням каскадного підходу обробки деревини в Чехії з урахуванням соціальних та економічних показників. У рамках даного дослідження авторами було перевірено три сценарії побудови потокового типу виробництва з урахуванням соціальних та економічних показників: кількість робітників, соціальні та страхові внески (у т.ч. на 1 м³), додана вартість (у т.ч. на 1 м³), податок на прибуток (у т.ч. на 1 м³), обсяг продажів на 1 м³, обсяг продажів на одного працюючого. Перший сценарій враховує експортний потенціал наявних потужностей каскадної переробки деревини. Другий сценарій базується на першому та враховує параметри підвищення технологічної ефективності, третій - також базується на першому сценарії та враховує потенціал підвищення ефективності за рахунок залучення додаткових інвестицій в сегмент виробництва пиломатеріалів та целюлози. Результати дослідження показали, що для збалансування соціальних та економічних параметрів (створення нових робочих місць, підвищення попиту на висококваліфіковані кадри, підвищення заробітної плати, тощо) необхідним є створення відповідних умов для збільшення експортного потенціалу деревини. У той же час, доцільним є оптимізація структури виробництва шляхом максимізації потоку виробництва при каскадному типі обробки деревини, з урахуванням можливих змін обсягів та структури наявної деревини. Так, згідно отриманих результатів найбільш привабливими сценаріями є другий та третій. Таким чином, для підвищення технологічної та економічноі ефективності наявних потужностей деревообробної галузі у Чехії необхідним є залучення додаткових інвестиційних ресурсів у виробництво виробів з деревини та дерев'яних панелей.

Ключові слова: рух деревини, вартість деревини, дохід, додана вартість, зайнятість.

Manuscript received: 29.10.2018

(C) The author(s) 2018. This article is published with open access at Sumy State University. 